OPEN ACCESS

Edited by:

Rosanna Tofalo,

University of Teramo, Italy

Reviewed by:

Filippo Maggi,

University of Camerino, Italy

Miklós Takó,

University of Szeged, Hungary

*Correspondence:

Hazem S. Elshafie

hazem.elshafie@unibas.it

Specialty section:

This article was submitted to

Food Microbiology,

a section of the journal

Frontiers in Microbiology

Received: 06 August 2019

Accepted: 28 October 2019

Published: 19 November 2019

Citation:

Camele I, Elshafie HS, Caputo L and De Feo V (2019) Anti-quorum

Sensing and Antimicrobial Effect of Mediterranean Plant Essential Oils

Against Phytopathogenic Bacteria.

Front. Microbiol. 10:2619.

doi: 10.3389/fmicb.2019.02619

\section{Anti-quorum Sensing and Antimicrobial Effect of Mediterranean Plant Essential Oils Against Phytopathogenic Bacteria}

\author{
Ippolito Camele ${ }^{1}$, Hazem S. Elshafie ${ }^{1 *}$, Lucia Caputo ${ }^{2}$ and Vincenzo De Feo ${ }^{2}$ \\ ${ }^{1}$ School of Agricultural, Forestry, Food and Environmental Sciences, University of Basilicata, Potenza, Italy, ${ }^{2}$ Department \\ of Pharmacy, University of Salerno, Salerno, Italy
}

Essential oils (EOs) are one of the most interesting natural products extracted from different aromatic plants. For centuries, EOs have been considered an essential part of the traditional pharmacopeia. Many plant EOs have been reported as possible effective alternatives for commercial pesticides, and their single constituents have been used efficiently in food preservation for their promising anti-QS activity against several food pathogenic microorganisms. The current mini review gives a general overview over the microbicide effect as well as anti-quorum sensing and the anti-biofilm formation of some common plant EOs, especially those of Lamiaceae and Verbanaceae families; these are commonly grown in the Mediterranean region and are effective against some serious food phytopathogenic bacteria.

Keywords: natural products, postharvest disease, secondary metabolites, quorum sensing, biofilm

\section{INTRODUCTION}

Essential oils (EOs) are considered important natural products extracted from aromatic plants and have been used for centuries in traditional pharmacopeia (Elshafie and Camele, 2017). EOs can be identified as concentrated hydrophobic liquids containing volatile aromatic compounds (Camele et al., 2012; Elshafie et al., 2015b). They have several biological, nutritional, and pharmaceutical properties. Historically, they represent an important part of the traditional pharmacopeia (Elshafie et al., 2015a). In addition, several EOs have demonstrated interesting antimicrobial effects against many serious phytopathogenic fungi and bacteria, both in vitro and in vivo, as well as an effective use in the production of pharmaceutical drugs for plant and human diseases (Mancini et al., 2014; Elshafie and Camele, 2017). Bacterial biofilm is considered a severe hygiene problem in the environment, plant and human health, and in the food industry. Biofilms make bacteria more resistant to disinfectants and different antimicrobial agents (Jamal et al., 2018). Many plant EOs have showed promising anti-biofilm formation and quorum sensing (QS) effects (Poli et al., 2018). 
In this review, we give some more information about biofilm formation and the QS phenomenon, especially in food pathogenic bacteria. Moreover, this review illustrates the potential use of some plant EOs as anti-QS and biofilm agents to prevent bacterial infection and avoid the drug-resistance ability of many pathogenic bacteria.

\section{BIOFILM FORMATION AND QUORUM SENSING}

Biofilm formation is considered one of the most essential causes of bacterial resistance toward different traditional chemical and physical treatments and antimicrobial agents (Ivanova et al., 2018). Several animal and human microbial infections are related to microbial biofilm ability, which has recently become a real challenge (Coenye and Nelis, 2010).

Biofilm formation is highly related to the densitydependent cell communication called QS that plays an essential role in the biofilm development of many pathogenic microorganisms and triggers their resistance and virulence (Habeck, 2003). QS enables bacterial cells to have a multicellular behavior in prokaryotes and helps in regulating the virulence process, production of secondary metabolites, symbiosis, biofilm formation, induction of stationary phase responses, and motility for colony escape (Withers et al., 2001). QS allows bacteria cells to monitor their local population densities and regulate the timing of communal activities.

The most common bacterial food pathogens produce biofilms such as the Pseudomonas species, which are able to survive at high temperatures and reduce the shelf-life of foods and fish processing. In addition, Bacillus cereus, Escherichia coli, and Staphylococcus aureus were isolated from dairy processing lines, as reported by Kerekes et al. (2013).

Quorum sensing is a intercellular communication system that regulates microbe-microbe interactions (Nazzaro et al., 2019). The QS phenomenon regulates gene expression in response to the bacterial cell population size (Steindler and Venturi, 2007) and is expected to be the main function responsible for different bacterial phenotypes (Kumari et al., 2006; Duerkrop et al., 2007). Furthermore, most bacterial bioactive secondary metabolites are synthesized by stimulating some signal molecules that mediate the process of QS (Withers et al., 2001).

Several studies have shed light on the QS phenomenon in many gram-negative (G-ve) bacteria, including those pathogenic to plants and animals as well as human, such as the genus of Agrobacterium, Aeromonas, Burkholderia, Chromobacterium, Citrobacter, Enterobacter, Erwinia, Hafnia, Nitrosomonas, Obesumbacterium, Pantoea, Pseudomonas, Rahnella, Ralstonia, Rhodobacter, Rhizobium, Serratia, and Yersinia. In pathogenic species, the system may also enable coordination against the host, as in case of Pseudomonas aeruginosa infections in cystic fibrosis patients (Withers et al., 2001). Regarding P. aeruginosa, the opportunistic human pathogen, it secretes multiple extracellular virulence factors that cause extensive host tissue damage,

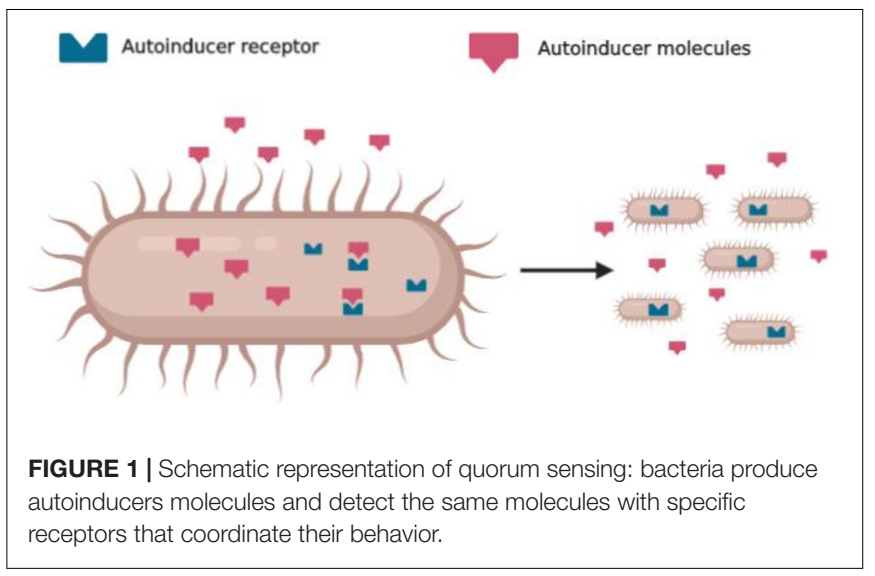

and these factors are regulated by the QS phenomenon, as reported by Gera and Srivastava (2006).

\section{SIGNAL MOLECULES MEDIATED QUORUM SENSING}

The QS system is based on different key elements, such as autoinducers, signal synthase, autoinducers receptors, and regulated genes (Figure 1). In general, G-ve bacteria use the LuxR/I-type and gram-positive $(\mathrm{G}+\mathrm{ve})$ bacteria use the peptide signaling system (Nazzaro et al., 2019). Signals molecules that mediate QS are oligopeptides in $\mathrm{G}+$ ve, $N$-Acyl-homoserine Lactones ( $N$-AHLs) in G-ve, and a family of autoinducers known as autoinducer-2 (AI-2) in both G-ve and G + ve (Miller and Bassler, 2001). In particular, the formation and the activation of $N$-AHLs are directly proportional to the bacterial density that enables them to act as a multicellular organism and become ready to make behavioral decisions (Withers et al., 2001).

$N$-AHLs are considered the main player in the bacterial pathogenesis (Miller and Bassler, 2001) as well as disease suppression by certain plant beneficial bacteria (Zhou et al., 2003). When the production of $N$-AHLs reaches a specific threshold concentration, corresponding to a critical population density, these signals serve as co-inducers to regulate the transcription of bacterial target genes that are responsible for the pathogenicity and production of bioactive secondary metabolites. On the other hand, autoinducers can also regulate the transcription of some bacterial genes as much as the cell density (Smith et al., 2003). Autoinducers are able to coordinate a suite of virulence factors: antibiotic production (Stead et al., 1996), biofilm formation (Van Delden and Iglewski, 1998), luminescence, and swarming motility (Rasmussen et al., 2000).

\section{ANTI-BIOFILM AND QUORUM SENSING EFFECTS OF EOs}

EOs are composed mainly from two groups of single substances, terpenoids (monoterpene, sesquiterpene and di-terpene) 
and phenylpropanoids (Nieto, 2017). The terpenoid group includes several compounds commonly present in the chemical composition of many plant EOs with different percentages, such as $p$-cymene, pinene, limonene, sabinene, and terpinene (Kerekes et al., 2015), geraniol, menthol, linalool, citronellol, carvone, thymol, carvacrol, geranyl acetate, eugenyl acetate, geranial, neral, and 1,8-cineole (Ayala-Zavala et al., 2007; Nieto, 2017). In addition, phenylpropanoids include several aromatic compounds such as cinnamyl alcohol, cinnamaldehyde, eugenol, and methyl cinnamate (Hyldgaard et al., 2012). Since not all of the above compounds have anti-QS activity, an overview of the principal constituents of some common plant EOs extracted from different aromatic plants and that display anti-QS activity are reported in Table 1.

In particular, the family Lamiaceae is considered one of the most important families of medicinal and aromatic plants; it includes Origanum vulgare L., Majorana hortensis L., Thymus vulgaris L., Salvia officinalis L., Lavandula stoechas L., Hyptis suaveolens L., and Rosmarinus officinalis L. Besides that, Verbena officinalis L. (Verbenaceae), Carum carvi L. (Apiaceae), Citrus clementina Hort. ex Tan. (Rutaceae), Murraya koenigii (L.), and Sprengel (Rutaceae) are also considered important aromatic plants where their single constituents have promising anti-QS properties to combat different food pathogenic microorganisms, as reported in Table 1.

Origanum vulgare, one of the most efficient plant EOs, is able to counteract biofilm formation and the QS mechanism with its main bioactive constituents (carvacrol), which has explicated a promising effect against different food and human pathogenic bacteria, such as Salmonella enterica subsp. typhimurium and S. aureus (Asfour, 2018). In addition, other single constituents of oregano EO, such as linalool, limonene, (E)-citral, $\gamma$-terpinene, 1,8-cineole, and eugenol, have exhibited anti-QS effects, as reported in several studies (Raal et al., 2012; Al-Haidari et al., 2016).

Moreover, clary sage, juniper, lemon, and marjoram EOs have been examined in the food industry and showed an effective anti-QS effect by preventing biofilm formation, especially against B. cereus, E. coli, and Pichia anomala (Kerekes et al., 2013; Luciardi et al., 2016).

Benzaid et al. (2019) studied the anti-biofilm formation effect of mint EO on Candida albicans and concluded that this EO has reduced the biofilm formation of $C$. albicans. Marjoram EO also showed a promising anti-QS effect against Chromobacterium violaceum, the positive sensor strains for AHL-mediated QS (Kerekes et al., 2013). Poli et al. (2018) reported that Mentha suaveolens ssp. insularis acts as an inhibitor of violacein production and the biofilm

TABLE 1 | List of common plant EOs and their single constituents that display anti-QS activity.

\begin{tabular}{|c|c|c|c|c|c|}
\hline $\begin{array}{l}\text { Plant } \\
\text { scientific } \\
\text { name }\end{array}$ & Family & Essential oils & Raw materials & Principal bioactive constituents & References \\
\hline $\begin{array}{l}\text { Carum carvi (L.) } \\
\text { Sprengel }\end{array}$ & Apiaceae & Caraway & Fruits & $\begin{array}{l}\text { Limonene } 51 \% \text {, sabinene } 0.3 \%, \beta \text {-myrcene } 0.4 \% \text {, } \\
\beta \text {-pinene } 0.2 \% \text {, linalool } 0.2 \% \text {, Bornyl acetate }\end{array}$ & $\begin{array}{l}\text { Raal et al., 2012; Al-Haidari } \\
\text { et al., } 2016\end{array}$ \\
\hline $\begin{array}{l}\text { Origanum } \\
\text { vulgare L. }\end{array}$ & Lamiaceae & Oregano & Leaves & $\begin{array}{l}\text { Carvacrol } 75 \% \text {, linalool } 1.3 \% \text {, limonene } 1.3 \% \text {, (E)-citral } \\
2.5 \%, \gamma \text {-terpinene } 0.1 \%, 1,8 \text {-cineole } 0.2 \% \text {, eugenol } \\
1.2 \%\end{array}$ & $\begin{array}{l}\text { Mancini et al., 2014; Elshafie } \\
\text { et al., 2017; Asfour, } 2018\end{array}$ \\
\hline $\begin{array}{l}\text { Majorana } \\
\text { hortensis L. }\end{array}$ & Lamiaceae & Marjoram & Flowers & $\begin{array}{l}\alpha \text {-pinene } 9 \%, \beta \text {-pinene } 3.8 \% \text {, limonene } 6.4 \%, \\
1,8 \text {-cineole } 33.5 \%, \gamma \text {-terpinene } 0.1 \% \text {, linalol } 9.8 \%\end{array}$ & $\begin{array}{l}\text { Kerekes et al., 2013; Elshafie } \\
\text { et al., 2016a; Luciardi et al., } \\
2016\end{array}$ \\
\hline $\begin{array}{l}\text { Thymus } \\
\text { vulgaris L. }\end{array}$ & Lamiaceae & Thyme & Leaves & Carvacrol 3.5\%, p-cymene $11.2 \%$, terpinene $4.8 \%$ & $\begin{array}{l}\text { Elshafie et al., 2015a; Asfour, } \\
2018\end{array}$ \\
\hline $\begin{array}{l}\text { Salvia officinalis } \\
\text { L. }\end{array}$ & Lamiaceae & Sage & Leaves & $\begin{array}{l}\text { Camphor } 13.9 \% \text {, limonene } 1.4 \% \text {, } \alpha \text {-pinene } 4.4 \% \text {, } \\
\text { 1,8-cineole } 4.2 \%\end{array}$ & $\begin{array}{l}\text { Elshafie et al., 2016a; Asfour, } \\
2018\end{array}$ \\
\hline $\begin{array}{l}\text { Verbena } \\
\text { officinalis L. }\end{array}$ & Verbenaceae & Vervain & Leaves & $\begin{array}{l}\text { Limonene } 2.3 \%, 1.8 \text {-cineole, cis-Anethole } 0.2 \% \text {, linalol } \\
0.1 \% \text {, camphor } 0.2 \%\end{array}$ & $\begin{array}{l}\text { Duke, 1992; Rehecho et al., } \\
\text { 2011; Chalchat and Garry, } \\
1995\end{array}$ \\
\hline $\begin{array}{l}\text { Lavandula } \\
\text { stoechas L. }\end{array}$ & Lamiaceae & Lavender & Flowers & Fenchone $34.9 \%$, camphone $28.9 \%$ & Poli et al., 2018 \\
\hline $\begin{array}{l}\text { Citrus } \\
\text { clementina } \\
\text { Hort. ex Tan. }\end{array}$ & Rutaceae & Clementina & Peel & Sabinene $31.4 \%$, linalool 20.4\% & $\begin{array}{l}\text { Kerekes et al., 2013; Luciardi } \\
\text { et al., 2016; Poli et al., } 2018\end{array}$ \\
\hline $\begin{array}{l}\text { Murraya } \\
\text { koenigii (L.) } \\
\text { Sprengel }\end{array}$ & Rutaceae & Curry tree & Leaves & $\begin{array}{l}\text { Caryophyllene } 9.49 \% \text {, caryophyllene oxide } 1.02 \% \text {, } \alpha \text { - } \\
\text { and } \beta \text {-phellandrene } 0.07 \%, \alpha \text {-Terpinene } 2.37 \% \text {, linalool } \\
0.19 \%\end{array}$ & $\begin{array}{l}\text { Chowdhury et al., 2008; Bai } \\
\text { and Vittal, } 2014\end{array}$ \\
\hline $\begin{array}{l}\text { Hyptis } \\
\text { suaveolens L. }\end{array}$ & Lamiaceae & Pignut & Leaves & $\begin{array}{l}\text { Trans- } \beta \text {-caryophyllene } 11.3 \%, \alpha \text {-pinene }(2.3) \text {, } \\
\text { camphene } 2.6 \%, \beta \text {-myrcene } 1.5 \%, p \text {-cymene (11.2), } \\
\text { limonene }(7.2), \gamma \text {-terpinene }(1.5)\end{array}$ & Stashenko et al., 2013 \\
\hline $\begin{array}{l}\text { Rosmarinus } \\
\text { officinalis L. }\end{array}$ & Lamiaceae & Rosemary & Leaves & $\alpha$-pinene (26\%), 1,8-cineole (25\%), camphor 12\% & $\begin{array}{l}\text { Alvarez et al., 2012; Melito } \\
\text { et al., } 2019\end{array}$ \\
\hline
\end{tabular}


formation of C. violaceum, and the Carum copticum EO showed anti-QS activity against C. violaceum (Snoussi et al., 2018). Szabó et al. (2010) reported that EOs extracted from lavender, citrus, and rosemary plants can also inhibit QS and concluded that these EOs can be used in the pharmaceutical industry for discovering new therapy for serious human infections.

\section{MICROBICIDE EFFECT OF PLANT ESSENTIAL OILS}

Many foodborn pathogenic bacteria (FBPB) produce serious toxins that lead to food spoilage and human infection. Some of FBPB are characterized by the abovementioned phenomena of QS, such as E. coli, Listeria monocytogenes, Clostridium spp., S. enterica, and S. aureus (Martinoviæ et al., 2016).

In general, the use of antibiotics are the most common substances for the direct controlling of whole bacteria (Poli et al., 2018); however its use in the food industry sector for controlling FBPB is prohibited in most developed countries to avoid creating different resistant human strains. Furthermore, many synthetic preservatives used in the food industry with antimicrobial effects may causing allergies, intoxications, cancer, and other degenerative diseases (Aminzare et al., 2016). For instance, the scientific research has continuously been carried out to present new substances that can be effectively used in controlling FBPB, particularly as biofilm preventers and for the inactivation of QS in the food industry, against physical, chemical, and/or natural substances such as nanoparticles, antimicrobial polymers, hydrogel, ozone, and extracellular hydrolytic enzymes (Elshafie and Camele, 2017; Jiang et al., 2019).

Recently, there has been a great revolution in scientific research regarding the importance of using plant EOs in combating many pathogenic bacteria, especially against food spoilage and for human health (Khan et al., 2009; Olivero et al., 2010; Camele et al., 2012; Nieto, 2017).

In particular, many interesting EOs and their single components, extracted from oregano, sage, marjoram, and vervain in particular, have been used effectively against some post-harvest diseases (Mancini et al., 2014; Elshafie et al., 2015a, 2016a, 2017). The three EOs extracted from $V$. officinalis, M. hortensis, and S. officinalis (Elshafie et al., 2016a) and those extracted from leaves and fruits of Schinus terebinthifolius (Elshafie et al., 2016b) showed promising antimicrobial activity against some serious phytopathogens such as Colletotrichum acutatum, Botrytis cinerea, Clavibacter michiganensis, Xanthomonas campestris, and Pseudomonas syringae pv. phaseolicola.

Other plant Eos, such as O. vulgare, O. heracleoticum, and $O$. majorana, showed effective microbicide effects against some post-harvest pathogenic fungi (Aspergillus sp., Penicillium sp., Monilinia sp., and B. cinerea) and some phytopathogenic bacteria (Bacillus megaterium, C. michiganensis, X. campestris, and P. syringae pv. phaseolicola) (Della Pepa et al., 2019).

\section{MODE OF ACTION}

Many researchers have hypothesized that the possible mechanism behind the bioactivity of many EOs is due to their principal bioactive single molecules. In particular, the use of single components to control biofilm formation could be, in some cases, sufficient, such as $B$. cereus and E. coli (Kerekes et al., 2013); however, other studies explained that the synergism between different single components display better effects, like in case of the Listeria monocytogenes biofilm, where the synergism between a-pinene, limonene, and linalool substances can be more effective than each single component (Sandasi et al., 2009).

In addition, the synergic effect between different single constituents could trigger the antimicrobial effectiveness of EOs and may reduce the resistance of many pathogenic microorganisms (Elshafie et al., 2015b). Some single constituents can damage the cell walls and plasma membranes of microbial cells, alter morphology, and increase cell permeability (Elshafie et al., 2019). Adebayo et al. (2012) reported that carvacrol, $\gamma$-terpinene, and $p$-cymene could be effective on their own and also have a synergic effect when they are combined. This synergistic effect is due to the action of $p$-cymene, which works as mediator for transportation of carvacrol and $\gamma$-terpinene across the cell wall and cytoplasmic membrane of pathogenic microorganisms. On the other hand, the lipophilic properties of many single components play a role in degrading the microbe plasma membrane and, thus, lead to the lyses of the hypha wall (Elshafie and Camele, 2017).

\section{CONCLUSION}

The biofilm formation of pathogenic bacteria is considered a big challenge for the food industry and human/animal health. The QS mechanism regulates the bacterial biofilm formation; thus, destroying and/or disrupting this mechanism can help to prevent biofilm formation and then solve many health problems. Many plant EOs display promising antiQS properties by preventing biofilm formation, which could be very important in reducing the virulence and pathogenicity of drug-resistant bacteria, especially for those that are food pathogenic. In fact, the use of plant EOs in food industry do not change the organoleptic properties of foods, and their use could thus be a promising natural alternative for several synthetic food preservatives. Finally, many plant EOs can represent a possible substitute for many traditional antimicrobial drugs, which have a significant negative impact on the environment and human/animal health.

\section{AUTHOR CONTRIBUTIONS}

IC and HE conceived the study, provided the table, and wrote the manuscript. LC and VD revised the manuscript and provided the figure. 


\section{REFERENCES}

Adebayo, O., Dang, T., B'elanger, A., and Khanizadeh, S. (2012). Antifungal studies of selected essential oils and a commercial formulation against Botrytis Cinerea. J. Food Res. 2, 217-226. doi: 10.5539/jfr.v2n1p217

Al-Haidari, R. A., Shaaban, M. I., Ibrahim, S. R. M., and Mohamed, G. A. (2016). Anti-quorum sensing activity of some medicinal plants. Afr. J. Trad. Compl. Altern. Med. 13, 67-71. doi: 10.21010/ajtcam.v13i5.10

Alvarez, A., Garcia Garcia, B., Jordan, M. J., Martinez-Conesa, C., and Hernandez, M. D. (2012). The effect of diets supplemented with thyme essential oils and rosemary extract on the deterioration of farmed gilthead seabream (Sparus aurata) during storage on ice. Food Chem. 132, 1395-1405. doi: 10.1016/j. foodchem.2011.11.127

Aminzare, M., Hashemi, M., Azar, H. H., and Hejazi, J. (2016). The use of herbal extracts and essential oils as a potential antimicrobial in meat and meat products; a review. J. Hum. Environ. Health Promot. 1, 63-74. doi: 10.29252/ jhehp.1.2.63

Asfour, H. Z. (2018). Anti-quorum sensing natural compounds. J. Microsc. Ultrastruct. 6, 1-10. doi: 10.4103/JMAU.JMAU-10-18

Ayala-Zavala, J. F., Oms-Oliu, G., Odriozola-Serrano, I., Gonzalez-Aguilar, G. A., Alvarez-Parrilla, E., and Martin-Belloso, O. (2007). Biopreservation of fresh-cut tomatoes using natural antimicrobials. Eur. Food Res. Technol. 226, 1047-1055. doi: 10.1007/s00217-007-0630-z

Bai, J. A., and Vittal, R. R. (2014). Quorum sensing inhibitory and anti-biofilm activity of essential oils and their in vivo efficacy in food systems. Food Biotechnol. 28, 269-292. doi: 10.1080/08905436.2014.932287

Benzaid, C., Belmadani, A., Djeribi, R., and Rouabhia, M. (2019). The Effects of Mentha $\times$ piperita essential oil on C. albicans growth, transition, biofilm formation, and the expression of secreted aspartyl proteinases genes. Antibiotics 8, 1-15. doi: 10.3390/antibiotics8010010

Camele, I., Altieri, L., De Martino, L., De Feo, V., Mancini, E., and Rana, G. L. (2012). In vitro control of post-harvest fruit rot fungi by some plant essential oil components. Int. J. Mol. Sci. 13, 2290-2300. doi: 10.3390/ijms13022290

Chalchat, J.-C., and Garry, R.-P. (1995). Chemical composition of the leaf oil of Verbena officinalis L. J. Essent. Oil Res. 8, 419-420. doi: 10.1080/10412905.1996. 9700653

Chowdhury, J. U., Bhuiyan, N. I., and Yusuf, M. (2008). Chemical composition of the leaf essential oils of murrayakoenigii (L.) spreng and murrayapaniculata (L.). Bangladesh J. Pharmacol. 3, 59-63. doi: 10.3329/bjp.v3i2.841

Coenye, T., and Nelis, H. J. (2010). Review, in vitro and in vivo model systems to study microbial biofilm formation. J. Microbiol. Meth. 83, 89-105. doi: 10.1016/ j.mimet.2010.08.018

Della Pepa, T., Elshafie, H. S., Capasso, R., De Feo, V., Camele, I., Nazzaro, F., et al. (2019). Antimicrobial and phytotoxic activity of Origanum heracleoticum and O. majorana essential oils growing in cilento (Southern Italy). Molecules 24, 1-16. doi: $10.3390 /$ molecules 24142576

Duerkrop, B. A., Ulrich, R. L., and Greenberg, E. P. (2007). Octanoyl-homoserine lactone is the cognate signal for Burkholderia mallei BmaR1-BmaIl quorum sensing. J. Bacteriol. 189, 5034-5040. doi: 10.1128/JB.00317-07

Duke, J. A. (1992). Handbook of Phytochemical Constituent Grass, Herbs and other Economic Plants. Boca Raton, FL: CRC Press, 624.

Elshafie, H. S., Armentano, M. F., Carmosino, M., Bufo, S. A., De Feo, V., and Camele, I. (2017). Cytotoxic activity of Origanum vulgare L. on hepatocellular carcinoma cell line HepG2 and evaluation of its biological activity. Molecules 22, 1-16. doi: 10.3390/molecules22091435

Elshafie, H. S., and Camele, I. (2017). An overview of the biological effects of some mediterranean essential oils on human health (review article). Biomed. Res. Int. 2017, 1-14. doi: 10.1155/2017/9268468

Elshafie, H. S., Grul'ová, D., Baranová, B., Caputo, L., De Martino, L., Sedlák, V., et al. (2019). Antimicrobial activity and chemical composition of essential oil extracted from Solidago canadensis L. growing wild in slovakia. Molecules 2, 1-13. doi: $10.3390 /$ molecules 24071206

Elshafie, H. S., Mancini, E., Sakr, S., De Martino, L., Mattia, C. A., De Feo, V., et al. (2015b). Antifungal activity of some constituents of Origanum vulgare L. essential oil against postharvest disease of peach fruit. J. Med. Food 18, 929-934. doi: 10.1089/jmf.2014.0167

Elshafie, H. S., Mancini, E., Camele, I., Martino, L. D., and De Feo, V. (2015a). In vivo antifungal activity of two essential oils from mediterranean plants against postharvest brown rot disease of peach fruit. Indus. Crops Prod. 66, 11-15. doi: 10.1016/j.indcrop.2014.12.031

Elshafie, H. S., Sakr, S., Mang, S. M., De Feo, V., and Camele, I. (2016b). Antimicrobial activity and chemical composition of three essential oils extracted from mediterranean aromatic plants. J. Med. Food. 19, 1096-1103. doi: 10.1089/jmf.2016.0066

Elshafie, H. S., Ghanney, N., Mang, S. M., Ferchichi, A., and Camele, I. (2016a). An in vitro attempt for controlling severe phyto and human pathogens using essential oils from Mediterranean plants of genus Schinus. J. Med. Food 19, 266-273. doi: 10.1089/jmf.2015.0093

Gera, C., and Srivastava, S. (2006). Quorum-sensing: the phenomenon of microbial communication. Curr. Sci. 90, 666-677.

Habeck, M. (2003). Mistletoe compound enters clinical trials. Drug Discov. Today 8, 52-53. doi: 10.1016/S1359-6446(02)02571-0

Hyldgaard, M., Mygind, T., and Meyer, R. L. (2012). Essential oils in food preservation: mode of action, synergies, and interactions with food matrix components. Front. Microbiol. 3:12. doi: 10.3389/fmicb.2012.00012

Ivanova, A., Ivanova, K., and Tzanov, T. (2018). "Inhibition of quorum-sensing: a new paradigm," in Controlling Bacterial Virulence and Biofilm Formation, in Biotechnological Applications of Quorum Sensing Inhibitors, ed. V. C. Kalia, (Berlin: Springer Nature), 5-10.

Jamal, M., Ahmad, W., Andleeb, S., Jalil, F., Imran, M., Nawaz, M. A., et al. (2018). Bacterial biofilm and associated infections. J. Chin. Med. Assoc. 81, 7-11. doi: 10.1016/j.jcma.2017.07.012

Jiang, Q., Chen, J., Yang, C., Yin, Y., and Yao, K. (2019). Quorum sensing: a prospective therapeutic target for bacterial diseases. BioMed. Res. Int. 2019:15. doi: 10.1155/2019/2015978

Kerekes, E. B., Deák, É, Takó, M., Tserennadmid, R., Petkovits, T., and Vágvölgyi, C. (2013). Anti-biofilm forming and anti-quorum sensing activity of selected essential oils and their main components on food-related micro-organisms. J. Appl. Microbiol. 115, 933-942. doi: 10.1111/jam.12289

Kerekes, E. B., Vidács, A., Török Jenei, J., Gömöri, C., Takó, M., Chandrasekaran, M., et al. (2015). "Essential oils against bacterial biofilm formation and quorum sensing of food-borne pathogens and spoilage microorganisms," in The Battle Against Microbial Pathogens: Basic Science, Technological Advances and Educational Programs, ed. A. Méndez-Vilas (Bajadoz: Formatex Research Center), 429-437.

Khan, M. S. A., Zahin, M., Hasan, S., Husain, F. M., and Ahmad, I. (2009). Inhibition of quorum sensing regulated bacterial functions by plant essential oils with special reference to clove oil. Lett. App. Microbiol. 49, 354-360. doi: 10.1111/j.1472-765X.2009.02666.x

Kumari, A., Pasini, P., Deo, S. K., Flomenhoft, D., Shashidhar, H., and Daunert, S. (2006). Biosensing systems for the detection of bacterial quorum signaling molecules. Anal. Chem. 78, 7603-7609. doi: 10.1021/ac061421n

Luciardi, M. C., Blázquez, M. A., Cartagena, E., Bardón, A., and Arena, M. E. (2016). Mandarin essential oils inhibit quorum sensing and virulence factors of Pseudomonas aeruginosa. LWT Food Sci. Technol. 68, 373-380. doi: 10.1016/ j.lwt.2015.12.056

Mancini, E., Camele, I., Elshafie, H. S., De Martino, L., Pellegrino, C., Grulova, D., et al. (2014). Chemical composition and biological activity of the essential oil of Origanum vulgare ssp. hirtum from different areas in the southern apennines (Italy). Chem. Biodiver. 11, 639-651. doi: 10.1002/cbdv.20130 0326

Martinoviæ, T., Andjelkoviæ, U., Gajdošik, M. S., Rešetar, D., and Josiæ, D. (2016). Foodborne pathogens and their toxins. J. Proteomics 147, 226-235. doi: 10.1016/ j.jprot.2016.04.029

Melito, S., Petretto, G. L., Chahine, S., Pintore, G., and Chessa, M. (2019). Seasonal variation of essential oil in Rosmarinus officinalis leaves in sardinia. Nat. Prod. Commun. 14, 1-17. doi: 10.1177/1934578X19864005

Miller, M. B., and Bassler, B. L. (2001). Quorum sensing in bacteria. Annu. Rev. Microbiol. 55, 165-199. doi: 10.1146/annurev.micro.55.1.165

Nazzaro, F., Fratianni, F., d'Acierno, A., De Feo, V., Ayala-Zavala, F. J., Gomes-Cruz, A., et al. (2019). "Effect of polyphenols on microbial cellcell communications," in Quorum Sensing: Molecular Mechanism and Biotechnological Application, ed. G. Tommonaro (Cambridge, MA: Academic Press), 195-223. doi: 10.1016/b978-0-12-814905-8.00008-3

Nieto, G. (2017). Biological activities of three essential oils of the lamiaceae family. Medicines 4, 1-10. doi: 10.3390/medicines4030063 
Olivero, J. T. V., Pàjaro, C. N. P., and Stashenko, E. (2010). Antiquorum sensing activity of essential oils isolated from different species of the genus piper. Vitae $18,77-82$.

Poli, J. P., Guinoiseau, E., Serra, D. R., Sutour, S., Paoli, M., Tomi, F., et al. (2018). Anti-Quorum Sensing activity of 12 essential oils on Chromobacterium violaceum and specific action of cis-cis-p-menthenolide from corsican Mentha suaveolens ssp. Insularis. Molecules 23, 1-11. doi: 10.3390/molecules2309 2125

Raal, A., Arak, E., and Orav, A. (2012). The content and composition of the essential oil Found in Carum carvi L. commercial fruits obtained from different countries. J. Essen. Oil Res. 24, 53-59. doi: 10.1080/10412905.2012.646016

Rasmussen, T. B., Manefield, M., Anderson, J. B., Eberl, L., Anthoni, U., Christopherson, C., et al. (2000). How Delisea pulchra furanones affect quorum sensing and swarming motility in Serratia liquefaciens MG1. Microbiology 146, 3237-3244. doi: 10.1099/00221287-146-12-3237

Rehecho, S., Hidalgo, O., de Cirano, M. G.-I., Navarro, I., Astiasarán, I., Ansorena, D., et al. (2011). Chemical composition, mineral content and antioxidant activity of Verbena officinalis L. LWT Food Sci. Technol. 44, 875-882. doi: 10.1016/j.lwt.2010.11.035

Sandasi, M., Leonard, C. M., and Viljoen, A. M. (2009). The in vitro antibiofilm activity of selected culinary herbs and medicinal plants against Listeria monocytogenes. Lett. Appl. Microbiol. 50, 30-35. doi: 10.1111/j.1472-765X.2009. 02747.x

Smith, K. M., Bu, Y., and Suga, H. (2003). Induction and inhibition of Pseudomonas aeruginosa quorum sensing by synthetic autoinducer analogs. Chem. Biol. 10, 81-89. doi: 10.1016/S1074-5521(03)00002-4

Snoussi, M., Noumi, E., Punchappady-Devasya, R., Trabelsi, N., Kanekar, S., Nazzaro, F., et al. (2018). Antioxidant properties and anti-quorum sensing potential of Carum copticum essential oil and phenolics against Chromobacterium violaceum. J. Food Sci. Technol. 55, 2824-2832. doi: 10.1007/ s13197-018-3219-6

Stashenko, E. E., Martínez, J. R., Cala, M. P., Durán, D. C., and Caballero, D. (2013). Chromatographic and mass spectrometric characterization of essential oils and extracts from Lippia (Verbenaceae) aromatic plants. J. Separ. Sci. 36, 192-202. doi: $10.1002 /$ jssc. 201200877

Stead, P., Rudd, B. A., Bradshaw, H., Noble, D., and Dawson, M. J. (1996). Induction of phenazine biosynthesis in cultures of Pseudomonas aeruginosa by L-N-(3-oxohexanoyl) homoserine lactone. FEMS Microbiol. Lett. 140, 15-22. doi: 10.1111/j.1574-6968.1996.tb08308.x

Steindler, L., and Venturi, V. (2007). Detection of quorum-sensing N-acyl homoserine lactone signal molecules by bacterial biosensors. FEMS Microbiol. Lett. 266, 1-9. doi: 10.1111/j.1574-6968.2006.00501.x

Szabó, M. Á, Varga, G. Z., Hohmann, J., Schelz, Z., Szegedi, E., Amaral, L., et al. (2010). Inhibition of quorum-sensing signals by essential oils. Phytother. Res. 24, 782-786. doi: 10.1002/ptr.3010

Van Delden, C., and Iglewski, B. H. (1998). Cell-to-cell signaling and Pseudomonas aeruginosa infections. Emerg. Infect. Dis. 4, 1-13. doi: 10.3201/eid0404.98 0405

Withers, H., Swift, S., and Williams, P. (2001). Quorum sensing as an integral component of gene regulatory networks in gram-negative bacteria. Curr. Opin. Microbiol. 4, 186-193. doi: 10.1016/S1369-5274(00)00 187-9

Zhou, H., Yao, F., Roberts, D. P., and Lessie, T. G. (2003). AHL-Deficient mutants of Burkholderia ambifaria BC-F have decreased antifungal activity. Curr. Microbiol. 47, 174-179. doi: 10.1007/s00284-002-3926-Z

Conflict of Interest: The authors declare that the research was conducted in the absence of any commercial or financial relationships that could be construed as a potential conflict of interest.

Copyright (c) 2019 Camele, Elshafie, Caputo and De Feo. This is an open-access article distributed under the terms of the Creative Commons Attribution License (CC BY). The use, distribution or reproduction in other forums is permitted, provided the original author(s) and the copyright owner(s) are credited and that the original publication in this journal is cited, in accordance with accepted academic practice. No use, distribution or reproduction is permitted which does not comply with these terms. 